\title{
Evidence Based Evaluation of Pharmacological Activity and Herb-Herb interaction of Organic Extracts of Certain Natural Anti- Diabetic Mixtures
}

\author{
Asmaa Sayed Abd Elkarim ${ }^{1, *}$, Amal H. Ahmed², Abdelbaset M. Elgamal', Radwan El Haggar ${ }^{4}$, Alaa Khedr ${ }^{5}$, \\ Mohamed Fouad Shalaby ${ }^{5}$, Roula Bayram ${ }^{5}$, Samah Shabana ${ }^{5}$
}

Asmaa Sayed Abd Elkarim ${ }^{1, *}$, Amal H. Ahmed ${ }^{2}$, Abdelbaset M. Elgamal $^{3}$, Radwan El Haggar ${ }^{4}$, Alaa Khedr ${ }^{5}$, Mohamed Fouad Shalaby ${ }^{5}$, Roula Bayram ${ }^{5}$, Samah Shabana ${ }^{5}$

'Chemistry of Tanning Materials and Leather Technology Department, National Research Centre, 33 El Bohouthst. (former EL Tahrirst.)Dokki-Giza, EGYPT.

2Pharmacognosy Department, Faculty of Pharmacy, Al-azhar University, 11884 Nasr City, Cairo, EGYPT.

${ }^{3}$ Chemistry of Natural and Microbial Products Department, National Research Centre, 33

El Bohouth st. (former EL Tahrir st.)-DokkiGiza-EGYPT.

${ }^{4}$ Pharmaceutical Chemistry Department,

Faculty of Pharmacy, Helwan University, Cairo 11795, EGYPT

${ }^{5}$ Department of pharmacognosy, Faculty of Pharmaceutical Sciences and Drug Manufacturing, Misr University for Science and Technology, MUST, 6th October City, EGYPT.

\section{Correspondence}

\section{Asmaa Sayed Abd Elkarim}

Chemistry of Tanning Materials and

Leather Technology Department, National

Research Centre, 33 El Bohouthst.

(former EL Tahrirst.)-Dokki-Giza, EGYPT.

Phone no: 01000780829

E-mail: asmaa_nrc@yahoo.com

History

- Submission Date: 06-07-2021;

- Review completed: 12-08-2021;

- Accepted Date: 16-08-2021.

DOI : 10.5530/pj.2021.13.173

Article Available online

http://www.phcogj.com/v13/i6

Copyright

(C) 2021 Phcogj.Com. This is an openaccess article distributed under the terms of the Creative Commons Attribution 4.0 International license.

\begin{abstract}
Objective: This work aims to find a new treatment based on the development of safe natural anti-diabetic mixtures. It assesses the hypoglycemic activity of natural mixtures and determines whether there are any negative side effects from the interaction of the herbs and the herbs. Methods: Six natural mixtures were tested for anti-diabetic activity, which was confirmed by a pathological histological examination. We performed a GC-MS analysis on active mixtures 1 and 2, yielding 54 and 38 compounds, respectively. The major compounds were Gingerol, Butan-2-one and 4-(3-hydroxy-2-methoxyphenyl) (97 and 64.02 per cent). Results: Among the six samples, the organic extract of mixture 1 and 2 showed a significant reduction in BGL compared to the standard drug glimepiride at a dose of $10 \mathrm{mg} / \mathrm{kg}$ ip and demonstrated a beneficial effect on renal function in alloxan-induced diabetic mice. These results were confirmed by a histopathological study which revealed that both mixture 1 and mixture 2 had decreased morphological and ultrastructural changes in the triggered liver. Docking of cuminaldehyde, Gingerol and $\alpha$-Copaenin at the active site of human pancreatic enzymes $\alpha$-amylase and aldol reductase revealed that these compounds had binding affinity at the active site of the enzymes. Conclusion: Our results revealed the anti-diabetic activity of non-polar mixtures consisting of long chain hydrocarbons, oils and non-polar components, thus suggesting that the herbal formulation is safe and effective for the treatment and complication of type 2 diabetes.
\end{abstract}

Key words: Anti-diabetic herbs, Herb-herb interaction, Medicinal plants.

\section{INTRODUCTION}

Diabetes mellitus (DM) is a chronically high blood glucose disease that causes a major symptom of the flow of large amounts of sweet urine. The basic abnormality is insulin deficiency ${ }^{1}$. Recent estimates show that 382 million people worldwide have been identified as suffering from DM in 2013 and are expected to rise to 592 million by 2035 , with equally increasing physiological, psychological and economic burdens on humans with life-threatening consequences ${ }^{2-6}$. Diabetic animal models using alloxan chemical induction could provide valuable information on the natural history of non-alcoholic fatty liver disease and improve our understanding of the mechanisms underlying this condition and its progression in diabetic patients ${ }^{7}$. According to previous literature reviews, cellular oxidative stress plays an important role in the progression of hyperglycemia-related output in diabetes may initiate or facilitate the development of chronic diabetic lesions in vessels, retinas, kidneys, nerves, and other organs if the diabetic organism's antioxidant defences are unable to inhibit the harmful action of those substances ${ }^{8-10}$. Because herbal anti-diabetic medicines were not yet commercially produced in the same quantities as modern medicines, our research focused on determining the hypoglycemic activity of natural mixtures and whether there were any negative side effects. As a result of the interaction of herbs and herbs ${ }^{11}$. It also hopes to find a safe combination of tissue injury and increased reactive oxygen species commercially available.

Literature review had been conducted for searching about the medicinal plants and natural products those reported to have strong antidiabetic activity and compared this study with them. We have found that more than 17 species of plants with hypoglycemic activity as a result of its richness in, alkaloids, terpenoids, flavonoids, carotenoids, and other compounds that have anti-diabetic properties. They were Acacia Arabica, Allium sativum, Aloe vera, Coffea Arabica, Vaccinium Cyanococcus, Cinnamomum Zeylanicum, Camellia sinensis, Ginkgo biloba, Zingiberofficinale, Glycyrrhizaglabra, Linumusitatissimum, Trigonella foenum-graecum, Momordicacharantia, Carumcarvi, Coriandrumsativum, Curcuma longa and Olea europaea. ${ }^{12}$. The aim of this study was to discover a healthy natural medicinal mixture with enhanced efficacy in treating diabetes.

\section{MATERIALS AND METHODS}

\section{Design of natural mixtures}

According to conducted literature review, samples of natural products that were reported to have antidiabetic activity were purchased from the local markets in Jeddah, KSA and authenticated by Dr. Samah Shabana through using The Egyptian pharmacopoeia. These samples were cleaned, shadow dried, and grinded to powder then divided to six natural mixtures were designed as shown in table 1. these herbs which are used to treat diabetes and are

Cite this article: Elkarim ASA, Ahmed AH, Elgamal AM, Haggar REL, Khedr A, Shalaby MF, et al. Evidence Based Evaluation of Pharmacological Activity and Herb-Herb interaction of Organic Extracts of Certain Natural Anti-Diabetic Mixtures. Pharmacogn J. 2021;13(6): 1366-1376. 
Table 1: Natural mixtures that were screened for their anti-diabetic activity.

\begin{tabular}{|c|c|c|}
\hline Mixture & Natural products & Weight \\
\hline Mixture 1 & $\begin{array}{l}\text { Blueberry (VacciniumCyanococcus) } \\
\text { Cinnamon (Cinnamomumzeylanicum) } \\
\text { Green tea (Camellia sinensis) } \\
\text { Ginkgo (Ginkgo biloba) }\end{array}$ & $\begin{array}{l}50 \mathrm{mg} \\
50 \mathrm{mg} \\
50 \mathrm{mg} \\
100 \mathrm{mg}\end{array}$ \\
\hline Mixture 2 & $\begin{array}{l}\text { Green tea (Camellia sinensis) } \\
\text { Ginger (Zingiber officinale) } \\
\text { Liquorice (Glycyrrhiza glabra) } \\
\text { Fenugreek (Trigonella foenum-graecum) } \\
\text { Bitter melon (Momordica charantia) }\end{array}$ & $\begin{array}{l}150 \mathrm{mg} \\
150 \mathrm{mg} \\
150 \mathrm{mg} \\
150 \mathrm{mg} \\
150 \mathrm{mg}\end{array}$ \\
\hline Mixture 3 & $\begin{array}{l}\text { Caraway (Carum carvi) } \\
\text { Coriander (Coriandrum sativum) } \\
\text { Green tea (Camellia sinensis) }\end{array}$ & $\begin{array}{l}50 \mathrm{mg} \\
50 \mathrm{mg} \\
50 \mathrm{mg}\end{array}$ \\
\hline Mixture 4 & $\begin{array}{l}\text { Ginger (Zingiber officinale) } \\
\text { Garlic (Allium sativum) } \\
\text { Fenugreek (Trigonella foenum-graecum) } \\
\text { Turmeric (Curcuma longa) } \\
\text { Olives leaves (Olea europaea) }\end{array}$ & $\begin{array}{l}100 \mathrm{mg} \\
100 \mathrm{mg} \\
100 \mathrm{mg} \\
100 \mathrm{mg} \\
100 \mathrm{mg}\end{array}$ \\
\hline Mixture 5 & $\begin{array}{l}\text { Fenugreek (Trigonella foenum-graecum) } \\
\text { Aloe (Aloe vera) } \\
\text { Linseed (Linum usitatissimum) } \\
\text { Gum acacia (Acacia senegal) }\end{array}$ & $\begin{array}{l}150 \mathrm{mg} \\
150 \mathrm{mg} \\
150 \mathrm{mg} \\
150 \mathrm{mg}\end{array}$ \\
\hline Mixture 6 & $\begin{array}{l}\text { Liquorice (Glycyrrhiza glabra) } \\
\text { Caffeine } \\
\text { Ginkgo (Ginkgo biloba) }\end{array}$ & $\begin{array}{l}200 \mathrm{mg} \\
200 \mathrm{mg} \\
100 \mathrm{mg}\end{array}$ \\
\hline
\end{tabular}

\section{Preparation of crude extracts and fractionation}

Powder of each mixture was macerated in $600 \mathrm{ml}$ of $70 \%$ ethanol for about one week. The macerated mixtures were filtered, and then $50 \mathrm{ml}$ of filtrate concentrated to dryness in a rotary evaporator under reduced pressure.

The remaining water residue of each extract was macerated in dichloromethane with the solvent: solute ratio of 3: 1 for $48 \mathrm{~h}$ with frequent shaking using separating funnel to separate aqueous extract from organic one.

Organic fractions were dried under vacuum. The dried extracts were weighted and dissolved in a definite amount of sesame oil for making dose of $10 \mathrm{mg} / \mathrm{Kg}$ which will subjected to investigation of its antidiabetic activity.

\section{Investigation of antidiabetic activity of natural mixtures}

\section{Animals}

54 male adult albino mice weighting 25 to $30 \mathrm{~g}$ were used from the animal house, Batterjee Medical College. The animals were maintained under standard environmental conditions with free access to feed and water during the experimental period in ventilated cages.

The animals were fasted for 16 hours before the experiment but allowed free access to water. All experiments were performed in the morning according to current guidelines for the care of laboratory animals and the ethical guidelines for investigations of experimental pain in conscious animals. As some suffering might result from these experiments, the Batterjee medical college committee for research and ethical guidelines were followed.

The animals were kept on solid floored cages with a deep layer of sawdust to accommodate the excess of urination and cages were changed daily. All animals were euthanized by thiopental (intravenous injection, $150 \mathrm{mg} / \mathrm{kg}$ ) for tissue collection.

\section{Alloxan-induced diabetic mice}

$120 \mathrm{mg} / \mathrm{kg}$ of Alloxan monohydrate freshly prepared in saline then will be injected intraperitoneal to overnight fasted animals. After that, the animals were given Glucose (5\% solution) in the drinking water to prevent hypoglycemia for the next 24 hours. The non-diabetic mice will exclude from the study, and diabetes establish with non-fasting blood glucose levels of more than $200 \mathrm{mg} / \mathrm{dl}^{13}$.

\section{STUDY DESIGN}

The diabetic mice (glucose $>200 \mathrm{mg} / \mathrm{dl}$ ) were divided into 9 groups of 6 animals each. Group I served as control received $1 \%$ gum acacia, group II served as diabetic control received $5 \%$ gum acacia, group III treated with standard glimepiride at a dose of $10 \mathrm{mg} / \mathrm{kg}^{14}$. Group IV, V, VI, VII, VIII and IX received organic extract of 6 different herbal mixtures at a dose of $10 \mathrm{mg} / \mathrm{kg}^{15}$.

The freshly prepared solutions were administered daily IP for 7 days. It is better to use IP over gavage to avoid loss of quantity during the absorption phase (Table 2).

\section{Determination of blood glucose level}

Blood glucose levels were tested on the 0 day, 2st, 4th, 6th and 8st days from the start of the experiment. Blood samples were collected from the tail of the fasting animals. One millimeter of its end was cut and a drop of blood was used for blood glucose test using advanced glucometer (Roche, USA). The accuracy of glucometer was checked with O-toluidine method ${ }^{16}$.

\section{Biochemical analysis}

Blood was collected from the retro-orbital venous plexus according to the method of kept at $37^{\circ} \mathrm{C}$ for $30 \mathrm{~min}$, and centrifuged by $3000 \mathrm{RPM}$ for $6 \mathrm{~min}$. Then the separated serum was stored at $-20^{\circ} \mathrm{C}$ for various biochemical analyses. The serum urea concentration was determined by the method for estimation of kidney function using urea diagnostic $\mathrm{kit}^{17}$. A liver function test including determination of albumin in serum was done using albumin diagnostic $\mathrm{kit}^{18}$.

\section{Histopathological studies}

At the end of the experiment, the whole liver tissues from each animal were removed after cervical dislocation, and a portion of the liver was cut into two to three pieces of approximately $6 \mathrm{~mm} 3$ sizes and fixed in 40 percent formalin saline were dehydrated by successfully passing through different mixtures of ethyl alcohol-water, cleaned in xylene, and embedded in parafin. Thin sections of liver tissue were cut at $5 \mathrm{~m}$ thickness and stained with haematoxylin and eosin dye (H\&E) before being mounted in neutral de-paraffinized xylene (DPX) medium for microscopic examination. The thin liver sections were mounted on permanent slides and examined under high resolution microscopy ${ }^{19}$.

\section{Table 2: The animals were divided into 9 groups as follow.}

$\begin{array}{ll}\text { Group I } & \begin{array}{l}\text { Negative control mice } \\ \text { Group II }\end{array} \\ \text { Positive control (diabetic control mice) } \\ \text { Group III } & \begin{array}{l}\text { Diabetic mice treated with glimepiride. The drug was given IP } \\ (10 \mathrm{mg} / \mathrm{kg}) \text { for } 1 \text { week }\end{array} \\ \text { Group IV } & \begin{array}{l}\text { Diabetic mice treated with organic extract of mixture } 1 \text { at dose } \\ 10 \mathrm{mg} / \mathrm{kg} \text { IP for } 1 \text { week }\end{array} \\ \text { Group V } & \begin{array}{l}\text { Diabetic mice treated with organic extract of mixture } 2 \text { at dose } \\ 10 \mathrm{mg} / \mathrm{kg} \text { IP for } 1 \text { week }\end{array} \\ \text { Group VI } & \begin{array}{l}\text { Diabetic mice treated with organic extract of mixture } 3 \text { at dose } \\ 10 \mathrm{mg} / \mathrm{kg} \text { IP for } 1 \text { week }\end{array} \\ \text { Group VII } & \begin{array}{l}\text { Diabetic mice treated with organic extract of mixture } 4 \text { at dose } \\ 10 \mathrm{mg} / \mathrm{kg} \text { IP for } 1 \text { week }\end{array} \\ \text { Group VIII } & \begin{array}{l}\text { Diabetic mice treated with organic extract of mixture } 5 \text { at dose } \\ 10 \mathrm{mg} / \mathrm{kg} \text { IP for } 1 \text { week }\end{array} \\ \text { Group IX } & \begin{array}{l}\text { Diabetic mice treated with organic extract of mixture } 6 \text { at dose } \\ 10 \mathrm{mg} / \mathrm{kg} \text { IP for } 1 \text { week }\end{array}\end{array}$




\section{STATISTICAL ANALYSIS}

The results of the experiments were presented as mean standard deviation. The GraphPad Prism Program was used for statistical analysis (GraphPad Software, Inc., San Diego, USA). Paired t-test was done to see any difference between the paired groups. The level of significance was set at $\mathrm{p}<0.05$.

\section{GC-MS Instrument and chromatographic conditions of the active organic extracts}

A Perkin Elmer Clarus 500 GC-MS (Perkin Elmer, Shelton, CT, USA) was utilized throughout the experiments. The software controller/ integrator was TurboMass version 5.4.2.1617. An Elite-1, GC capillary column, Cross bond ${ }^{\oplus} 100 \%$ dimethyl polysiloxane (30-meter $\times 0.25 \mathrm{~mm}$ ID $\times 0.25 \mu \mathrm{mdf}$, Perkin Elmer) was used. The carrier gas was helium (purity $99.9999 \%$ ) and flow rate was $0.9 \mathrm{~mL} / \mathrm{min}$. GC line temperature was $260^{\circ}$.

Electron energy was $70 \mathrm{eV}$, and trap-emission was $100 \mathrm{v}$. The oven was programmed where the initial temperature was $90^{\circ}$ (hold $4 \mathrm{~min}$ ) to $170^{\circ}$ (rate $10.0 \% \mathrm{~min}$, hold $10.0 \mathrm{~min}$ ), to $270^{\circ}$ (rate $10.0 \% \mathrm{~min}$, hold $8.0 \mathrm{~min}$ ). Injector temperature, $265^{\circ}$. The injection volume was $1.0 \mu \mathrm{L}$, and the Split was $60 \%$. Samples were acquired by applying the total ion chromatogram (TIC). The MS scan was from 50 to $450 \mathrm{~m} / \mathrm{z}$ (500 scan/ sec). An average TIC scan of each peak at definite retention times was saved using the TurboMass software to characterize the closed peaks obtained from the MS chromatogram of the analyzed samples.

\section{MOLECULAR DOCKING STUDIES}

In silico molecular docking simulation studies of identified compounds were done for three important enzymes involved in diabetes mellitus human pancreatic a-amylase (h-PA) (PDB-4GQR), human maltaseglucoamylase (h-MGAM-C) (PDB-3TOP) and human aldol reductase (h-ALR-2) (PDB- 4QXI) by using Molecular Operating Environment $\left(\mathrm{MOE}^{\circ}\right)$ version $2015.10^{20}$.

\section{Tested compounds optimization}

The tested compounds Cuminaldehyde, Gingerol, and a-Copaene were created into a 3D model using builder interface of the MOE program. The structures of the tested compounds were checked by $2 \mathrm{D}$ depiction, formal charges on atoms and then a conformational search was conducted. All conformers were subjected to energy minimization done with MOE using the default molecular mechanic force-field mmff $94 \mathrm{x}$. The database of tested compounds was then saved as MDB file for use in the molecular docking calculations.

\section{Optimization of protein active site}

The crystal structures of the h-PA, h-MGAM-C, and h-ALR-2 enzymes with their respective bounded ligands, Myricetin, Acarbose, and AK198 were obtained from the Protein Data Bank (www.pdb. org). The protein structures had been docking-ready by the addition of hydrogen atoms, as well as their standard geometry and energy minimization. MOE Alpha Site Finder searched for the active binding site in each receptor structure using all default items, and then dummy atoms were created.

\section{Docking of the tested compounds to protein active sites}

Docking of the tested compounds was performed using MOE-Dock software.To ensure a valid docking accuracy and to determine the water molecules effects, the co-crystallized ligand in each of the aforementioned enzymes was docked to its corresponding protein (in the presence and in the absence of water) and the RMSD values were calculated between the co-crystallized ligand and docked pose.
The success rates obtained were excellent and the active site of the each enzyme was saved as MOE file.

The active binding site files were then loaded, and the docking tools were used. The dummy atoms as docking site, triangle matcher as placement methodology, Londond $\mathrm{G}$ as scoring methodology have been adjusted to their default values. Finally, the MDB files of the tested compounds were loaded, and calculations for docking were run automatically retaining 30 docking poses.

The poses obtained were studied and the poses that showed the best ligand-receptor interactions were selected and stored for calculating energy.

\section{RESULTS AND DISCUSSION}

\section{Anti diabetic activity of natural mixtures \\ Blood glucose level}

As compared to the normal control group, alloxan caused a substantial rise in blood glucose levels. The organic extract of mixtures 1,2, 3 and 6 treated groups showed a substantial decrease $(\mathrm{P}<0,05)$ in blood glucose levels after one week of daily treatment compared to the diabetic control group. Herbal organic mixture extracts of 4 and 5 failed to show any hypoglycaemic activity after one week of treatment. Both of mixtures 1 and 2 showed a highest decrease in BGL as compared to the standard drug glimepiride treated group (Table 3 ).

\section{Biochemical mediators}

The mean values of blood urea nitrogen (BUN) CONC and blood albumin of both control and experimental groups were presented in Table 4. Alloxan-induced diabetic mice showed a significant increase $(\mathrm{p}<0.05)$ in serum urea nitrogen and decrease in serum albumin compared with the normal control. There was a significant restoration of these parameters to near normal after administration of the organic extracts of mixtures 1 and 2 more than the effect of glimepiride.

\section{HISTOPATHOLOGY INVESTIGATION}

Histopathology of the livers of mice in normal control group (figure 1) Displayed traditional hepatolobular architecture consisting of a central vein with hepatocyte radiating cords divided by sinusoids. The hepatocytes are polygonal in form, with core nuclei that are softly spotted, and conspicuous nuclei. The cytoplasm is spread regularly.

Diabetic mice treated with herbal mixture number 1 showed a protective effect on the tissue of the liver (Figure 1). Diabetic mice treated with herbal mixture number 2 displayed a marked decline in degeneration, drop in inflammation and loss of necrosis relative to diabetic control mice. Diabetic mice treated with herbal mixture number 3 showed an atrophy of the hepatocytes (A), vascular congestion (VC) and amyloidosis (AM) around the central vein in the liver tissue the same as diabetic control mice (Figure 1). Diabetic mice treated with herbal mixture number 6 showed a general Hepatocyte degeneration (HD), artery obstruction (VC), hepatocyte necrosis (NC) and penetration of the lymphocytes (Figure 1).

\section{GC-MS analysis of the organic extracts of active mixtures} (1and 2)

A variety of compounds have been identified by GC-MS examination of the organic extracts from natural mixtures 1 and 2 (figure 2). These compounds were characterized by GC-attached mass spectrometry. The numerous active components present in the dichloromethane extracts of mixtures 1 and 2 were detected by the GC-MS are shown in Table 5 and 6 respectively. 
Table 3: Effect of mixtures on BGL of alloxan-induced diabetic mice.

\begin{tabular}{|c|c|c|c|c|}
\hline \multirow{2}{*}{ Treatments } & \multicolumn{4}{|c|}{ Blood Glucose level (mg/dl) } \\
\hline & First Day & Third day & Fifth day & Seventh Day \\
\hline Normal Control gp & $123 \pm 11.4$ & $112 \pm 12.56$ & $105 \pm 11.41$ & $109 \pm 12.21$ \\
\hline Diabetic control gp & $424 \pm 38.43^{*}$ & $543 \pm 54.01^{*}$ & $527 \pm 51.21^{*}$ & $576 \pm 43.21^{*}$ \\
\hline Glimepiride treated gp $(10 \mathrm{mg} / \mathrm{kg})$ & $168.25 \pm 19.9^{\mathrm{a}}$ & $225 \pm 12.6^{\mathrm{a}}$ & $117.7 \pm 14.19^{\mathrm{a}}$ & $187.7 \pm 12.1^{\mathrm{a}}$ \\
\hline Mix 1 treated gp $(10 \mathrm{mg} / \mathrm{kg})$ & $257 \pm 24.2^{\mathrm{a}}$ & $208 \pm 19.3^{\mathrm{a}}$ & $170 \pm 14.3^{\mathrm{a}}$ & $166 \pm 20.9^{\mathrm{a}}$ \\
\hline Mix 2 treated gp $(10 \mathrm{mg} / \mathrm{kg})$ & $234 \pm 73.2^{\mathrm{a}}$ & $223 \pm 25.5^{\mathrm{a}}$ & $271 \pm 23.9^{\mathrm{a}}$ & $157 \pm 32.45^{\mathrm{a}}$ \\
\hline Mix 3 treated gp (10mg/kg) & $233 \pm 12.8^{\mathrm{a}}$ & $315 \pm 21.6^{\mathrm{a}}$ & $346 \pm 19.7^{\mathrm{a}}$ & $371.5 \pm 22.8^{\mathrm{a}}$ \\
\hline Mix 4 treated gp (10mg/kg) & $366 \pm 24.6^{\mathrm{a}}$ & $423 \pm 45.5^{\mathrm{a}}$ & $586 \pm 45.3$ & $491 \pm 50.9$ \\
\hline Mix 5 treated gp $(10 \mathrm{mg} / \mathrm{kg})$ & $397 \pm 29.1$ & $287 \pm 29.18^{\mathrm{a}}$ & $467 \pm 33.3$ & $600 \pm 54.5$ \\
\hline Mix 6 treated gp $(10 \mathrm{mg} / \mathrm{kg})$ & $522 \pm 54.3$ & $302 \pm 22.1^{\mathrm{a}}$ & $291 \pm 39.5^{\mathrm{a}}$ & $194 \pm 22.2^{\mathrm{a}}$ \\
\hline
\end{tabular}

*P $<0.05$ compared with normal control mice, ${ }^{a} \mathrm{P}<0.05$ compared with diabetic control mice

Table 4: Effects of daily administration of the organic extracts of herbal mixtures on serum level of urea and albumin in alloxan-induced diabetic mice for 1 week.

\begin{tabular}{lcc}
\hline Treatments & & Biochemical \\
Groups & & Mean \\
\hline Group1: Normal Control & $30.27 \pm 0.34$ & Albumin (g/dl) \\
Group2: Diabetic control & $47.71 \pm 7.92^{*}$ & $3.11 \pm 0.47$ \\
Group3: Glimepiride treated & $35.05 \pm 0.27 \mathrm{a}$ & $2.11 \pm 0.33^{*}$ \\
Group4: Mixture 1 treated & $32.21 \pm 0.01 \mathrm{a}$ & $2.17 \pm 0.6 \mathrm{a}$ \\
Group5: Mixture 2 treated & $27.95 \pm 1.83 \mathrm{a}$ & $3.97 \pm 0.01 \mathrm{a}$ \\
Group6: Mixture 3 treated & $35.46 \pm 0.01 \mathrm{a}$ & $0.99 \pm 0.01 \mathrm{a}^{*}$ \\
Group7: Mixture 5 treated & $41.416 \pm 2.33^{*}$ & $3.75 \pm 0.19^{*}$ \\
Group8: Mixture 6 treated & $43.58 \pm 4.43^{*}$ & $3.59 \pm 0.5^{*}$
\end{tabular}

* Significant different from normal control group,

a Significant different from diabetic control group.

Table 5: Normalized area percentage of GC-MS characterized compounds of dichloromethane extract of MIX1.

\begin{tabular}{|c|c|c|c|c|c|c|c|}
\hline Rt. Min & Name & $\mathrm{m} / \mathrm{z}$ & area \% & Rt. min & Name & $\mathrm{m} / \mathrm{z}$ & area $\%$ \\
\hline 3.087 & 2(z)-Heptenal & 112 & 2.65 & 8.908 & Parabanic acid & 128 & 0.41 \\
\hline 3.147 & Benzaldehyde & 106 & 1.03 & 9.399 & 4,4,6-Trimethyl-cyclohex-2-en-1-ol & 140 & 1.60 \\
\hline 3.457 & Caproic acid hexanoic) & 116 & 0.48 & 9.975 & 2-Undecenal & 168 & 0.61 \\
\hline 3.773 & 2.2-Amylfuran & 138 & 1.36 & 10.160 & N-Capric acid & 172 & 0.42 \\
\hline 3.853 & Caprylic aldehyde (Octanal) & 128 & 0.15 & 10.190 & Vanillin & 152 & 0.10 \\
\hline 3.953 & 6-Azabicyclo[3.2.1]octane & 111 & 0.14 & 10.496 & Ethyl caprate & 200 & 0.67 \\
\hline 4.028 & 2.4-Hydroxy-2-hexenoic acid lactone & 112 & 0.08 & 10.676 & Cumarin & 146 & 1.14 \\
\hline 4.434 & 3-Octen-2-one & 126 & 0.47 & 10.786 & trans-Cinnamic acid & 148 & 0.96 \\
\hline 4.785 & 2-Octenal & 126 & 1.66 & 11.673 & Azelaic acid monoethyl ester & 200 & 5.33 \\
\hline 5.055 & 1-Chlorooctane & 148 & 0.62 & 11.944 & 4-Hydroxy-2-methoxycinnamaldehyde & 162 & 0.96 \\
\hline 5.176 & Pentylcyclopropane & 112 & 0.29 & 12.219 & L-calamenene & 202 & 0.49 \\
\hline 5.266 & Enanthylic acid & 130 & 0.13 & 12.730 & Lauric acid (Dodecanoic) & 200 & 2.59 \\
\hline 5.727 & Pelargonaldehyde & 142 & 1.81 & 13.116 & Dodecanoic acid, ethyl ester & 228 & 2.75 \\
\hline 5.932 & Trans-2-heptenoic acid & 128 & 0.12 & 13.291 & 1-Cetene & 224 & 10.59 \\
\hline 6.704 & 2-Nonenal & 140 & 0.38 & 13.361 & Benzophenone & 182 & 1.11 \\
\hline 6.949 & Dimethylparabanic acid & 142 & 1.11 & 13.872 & Methyl 10-oxo-8-decenoate & 198 & 2.67 \\
\hline 7.139 & Caprylic acid & 144 & 1.00 & 14.724 & Paramethadione & 157 & 0.45 \\
\hline 7.465 & Ethyl caprylate & 172 & 0.67 & 16.617 & Myristic acid & 228 & 7.55 \\
\hline 7.605 & 2,4-Nonadienal & 138 & 0.88 & 17.409 & Ethyl myristate & 256 & 9.44 \\
\hline 7.771 & 2-Ethyl-3-methylmaleimide & 139 & 0.34 & 19.077 & 2-Pentadecanone, 6,10,14-trimethyl & 268 & 1.93 \\
\hline 7.891 & 2-Sec-Butylcyclohexanone & 154 & 0.55 & 20.886 & 7,9-Di-tert-butyl-1-oxaspiro(4,5)deca-6,9-diene-2,8-dione & 276 & 0.96 \\
\hline 7.951 & 2-Anisaldehyde & 136 & 0.24 & 24.217 & Palmitic acid & 256 & 56.13 \\
\hline 8.056 & Cuminaldehyde & 148 & 0.47 & 24.708 & Ethyl palmitate & 284 & 100.00 \\
\hline 8.226 & 2-Decenal & 154 & 0.96 & 26.361 & n-Heptadecanol-1 & 256 & 4.85 \\
\hline 8.317 & 2-Decen-1-ol & 156 & 0.36 & 27.603 & Steric acid & 284 & 2.73 \\
\hline 8.372 & Cinnamaldehyde & 132 & 6.59 & 27.984 & Stearic acid, ethyl ester & 312 & 14.53 \\
\hline 8.442 & 2-Decenal & 154 & 7.35 & 31.887 & Ethyl docosanoate & 368 & 1.00 \\
\hline
\end{tabular}

* Percentage of matching given by NIST2008 database. 
Table 6: Normalized area percentage of GC-MS characterized compounds of dichloromethane extract of MIX2.

\begin{tabular}{|c|c|c|c|c|c|c|c|}
\hline Rt, $\min$ & Name & $\mathrm{m} / \mathrm{z}$ & area $\%$ & Rt, min & Name & $\mathrm{m} / \mathrm{z}$ & area $\%$ \\
\hline 2.956 & 2-Heptenal, (E)- & 112 & 0.62 & 11.703 & Curcumin & 202 & 16.69 \\
\hline 3.087 & 2-Heptenal, (Z)- & 112 & 15.62 & 11.954 & $(+)-\beta$-Selinene & 204 & 3.92 \\
\hline 3.187 & 1,6-Octadiene, 3,7-dimethyl-, (S)- & 138 & 0.42 & 12.024 & $\gamma$-Murolene & 204 & 9.57 \\
\hline 3.402 & Caproic acid & 116 & 1.24 & 12.089 & $(+,-)-\beta$-Bisabolene & 204 & 2.98 \\
\hline 3.507 & 1-Octen-3-ol & 128 & 0.66 & 12.264 & $\beta$-Sesquiphellandrene & 204 & 8.12 \\
\hline 3.638 & 2,4-Heptadienal, (E,E) & 110 & 1.33 & 12.470 & coniferyl alcohol & 180 & 1.59 \\
\hline 3.813 & Caprylic aldehydes & 128 & 8.74 & 12.545 & Hedycaryol & 222 & 1.89 \\
\hline 6.027 & $\begin{array}{l}\text { Benzene, } 1-\text { methyl-4-(1- } \\
\text { methylpropyl) }\end{array}$ & 148 & 2.99 & 13.336 & Lanceol, cis & 220 & 2.76 \\
\hline 7.004 & Borneol & 154 & 2.31 & 13.542 & Butan-2-one, 4-(3-hydroxy-2-methoxyphenyl)- & 194 & 64.02 \\
\hline 7.390 & a-Terpinol & 154 & 1.16 & 13.647 & $\begin{array}{l}\text { Cyclopentanone, 3,3,4-trimethyl-4-(4- } \\
\text { methylphenyl)- }\end{array}$ & 216 & 11.39 \\
\hline 7.565 & Caprinaldehyde & 156 & 25.35 & 13.762 & Lanceol, cis & 220 & 5.56 \\
\hline 8.432 & 2-Decenal, $€$ & 154 & 3.17 & 14.063 & Benzenebutanal, $\gamma, 4$-dimethyl- & 176 & 14.39 \\
\hline 8.923 & 2,4-Decadienal & 152 & 6.60 & 14.128 & $\beta$-Selinenol & 222 & 2.62 \\
\hline 8.988 & 2-Undecanone & 170 & 1.37 & 14.729 & Lanceol, cis & 220 & 4.11 \\
\hline 9.243 & 2,4-Decadienal & 152 & 8.03 & 15.029 & Bergamotol, Z- $\alpha$-trans- & 220 & 7.19 \\
\hline 9.865 & $\begin{array}{l}\text { Carbamic acid, N-phenyl-, } \\
\text { 1-methyl-1-(4-methylcyclohex-3- } \\
\text { enyl)ethyl ester }\end{array}$ & 273 & 1.30 & 28.690 & Gingerol $(81 \%)^{*}$ & 294 & 100.00 \\
\hline 10.120 & N-Capric acid & 172 & 1.29 & 29.692 & Gingerol $(97 \%)^{*}$ & 294 & 59.50 \\
\hline 10.401 & Benzenebutanal, $\gamma$,4-dimethyl- & 176 & 1.45 & 30.815 & Gingerol $(59 \%)^{*}$ & 294 & 17.45 \\
\hline 10.476 & a-Copaene & 204 & 0.52 & 31.040 & $\begin{array}{l}\text { 2-(3,7-Dimethyl-octa-2,6-dienyl)-4-methoxy- } \\
\text { phenol }\end{array}$ & 260 & 5.48 \\
\hline
\end{tabular}

* Percentage of matching given by NIST2008 database.

Table 7: Energy docking ratings (kcal / mol) obtained from the MOE for compounds Cuminaldehyde, Gingerol, and a-copaenewith the corresponding ligands in h-PA, h-MGAM-C and h-ALR-2 enzymes.

\begin{tabular}{|c|c|c|c|c|c|c|c|c|}
\hline \multicolumn{9}{|c|}{ Human pancreatic a-amylase (h-PA) } \\
\hline Comp. No. & Score & rmsd_refine & \multicolumn{2}{|c|}{ E_conf } & E_place & E_score1 & E_refine & E_score2 \\
\hline Cuminaldehyde & -4.4331 & 1.8322 & \multicolumn{2}{|c|}{6.8487} & -28.0686 & -8.2481 & -17.8222 & -4.4331 \\
\hline Gingerol & -6.2050 & 1.4665 & \multicolumn{2}{|c|}{-21.4018} & -53.3649 & -12.1882 & -26.9625 & -6.2050 \\
\hline a-copaene & -4.9636 & 1.1082 & \multicolumn{2}{|c|}{52.3987} & -18.9712 & -7.7147 & -11.0097 & -4.9636 \\
\hline Myricetin & -5.5827 & 1.3889 & \multicolumn{2}{|c|}{-4.9237} & -69.1133 & -18.6686 & -24.8616 & -5.5827 \\
\hline \multicolumn{9}{|c|}{ Human maltase-glucoamylase (h-MGAM-C) } \\
\hline Cuminaldehyde & -5.0865 & 2.4575 & 6.4266 & -32.3048 & -7.1173 & -21.3311 & \multicolumn{2}{|c|}{-5.0865} \\
\hline Gingerol & -6.5708 & 1.6988 & -19.7463 & -52.6272 & -10.6130 & -31.2656 & \multicolumn{2}{|c|}{-6.5708} \\
\hline a-copaene & -4.5777 & 4.1419 & 45.1840 & -38.2187 & -7.6583 & -17.0778 & \multicolumn{2}{|c|}{-4.5777} \\
\hline Acarbose & -9.6234 & 1.5844 & 269.4543 & -37.6630 & -11.3820 & -54.9423 & \multicolumn{2}{|c|}{-9.6234} \\
\hline \multicolumn{9}{|c|}{ Human aldol reductase (h-ALR-2) } \\
\hline Cuminaldehyde & -5.1308 & 1.2869 & 6.5917 & -37.0623 & -8.0148 & -20.4488 & \multicolumn{2}{|c|}{-5.130} \\
\hline Gingerol & -7.8558 & 1.4574 & -18.3303 & -83.6102 & -13.8423 & -39.7450 & \multicolumn{2}{|c|}{-7.8558} \\
\hline$\alpha$-copaene & -5.3897 & 1.6761 & 52.3228 & -25.6032 & -9.1911 & -12.6999 & \multicolumn{2}{|c|}{-5.3897} \\
\hline AK198 & -8.0848 & 2.3050 & -51.3488 & -68.9124 & -11.3111 & -46.1859 & \multicolumn{2}{|c|}{-8.0848} \\
\hline
\end{tabular}

\section{Molecular docking of selected compounds}

Molecular docking is considered as an important tool to study the interactions between certain ligands and the binding site of the corresponding protein. In this study, to explore the molecular targets that might be involved in the herbal mixtures 1 and 2 antidiabetic mode of action, Cuminaldehyde, Gingerol, and $\boldsymbol{\alpha}$-copaene, which represent the antidiabetic components in the mixtures, were docked into the active binding sites of h-PA, h-MGAM-C and h-ALR-2 enzymes which are involved in the diabetes mellitus pathogenesis and complications ${ }^{21-23}$

The results were illustrated in (Table 7 and Figure 6). For h-PA enzyme that mediated starch digestion to produce maltose, maltotriose, and some other alpha 1, 4 and 1,6- linked oligo-glucans.
The binding free energy of the tested compounds exhibit favorable docked complexes with the active site of target protein with significant docking scores of $-4.4331,-6.2050$, and $-4.9636 \mathrm{kcal} / \mathrm{mol}$ for Cuminaldehyde, Gingerol, and $\boldsymbol{\alpha}$-copaene, respectively, compared with Myricetin docking score $(-5.5827 \mathrm{kcal} / \mathrm{mol}$ ) (Table 7).

Regarding the interactions at h-PA enzyme binding site, while, Cuminaldehyde showed binding interactions with HIS-101and ASP197, Gingerol and $\alpha$-copaene had binding interactions with TRP-59 compared to Myricetin that showed binding interactions with TRP-59 and ASP-300 (Figure 3-I).

On the other hand, for h-MGAM-C enzyme that is involved in the production of glucose units by hydrolyzing different oligoglucans. The binding free energy of the tested compounds showed docked complexes with the active site of the target protein with docking scores 

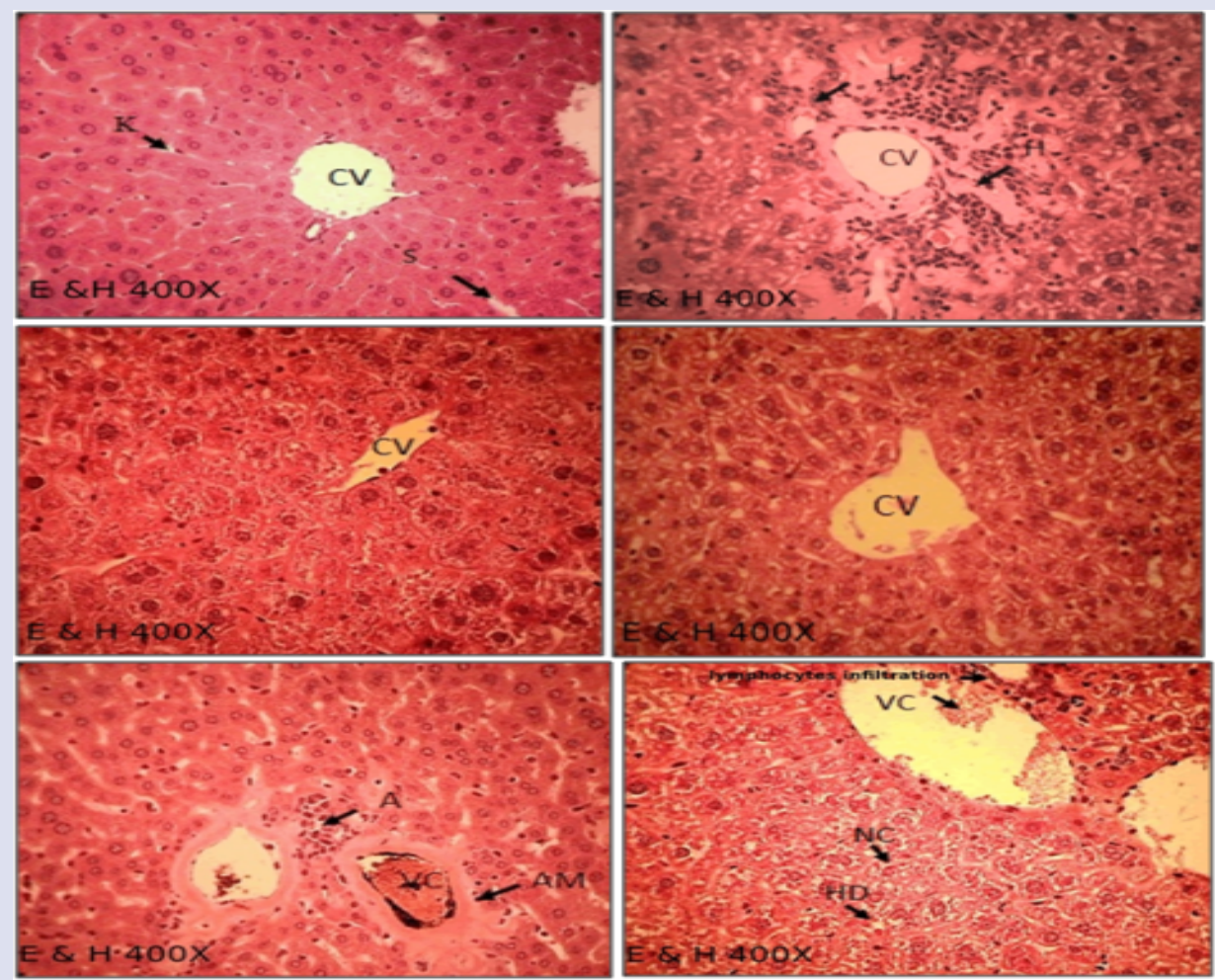

Figure 1A. A portion of normal mouse liver that displays natural liver architecture: central vein (CV), hepatocytes arranged in cord shape. Cords are divided from Kupffer cells (K) by the sinusoids (S). Figure 1B. A section of liver from diabetic control mouse displaying invasion of the lymphocytes (L), hepatocyte degeneration $(\mathrm{H})$ along central vein $(\mathrm{CV})$. Figure $1 \mathrm{C}$. A section of liver from diabetic mouse treated with herbal mixture number 1 showing decrease in congestion and absence in necrosis. Figure 1D. A sectional representative of liver from diabetic mouse treated with herbal mixture number 2 displaying reduced degeneration, reduced inflammation, and absence of liver necrosis. Figure 1E. A section of liver from diabetic mouse treated with herbal mixture number 3 showed an atrophy of the hepatocytes (A), vascular congestion (VC) and amyloidosis (AM) around the central vein in the liver tissue. Figure 1F. A portion of liver from diabetic mouse treated with herbal mixture number 6 demonstrating hepatocyte degeneration (HD), vascular obstruction (VC), hepatic necrosis (NC), and invasion of lymphocytes.

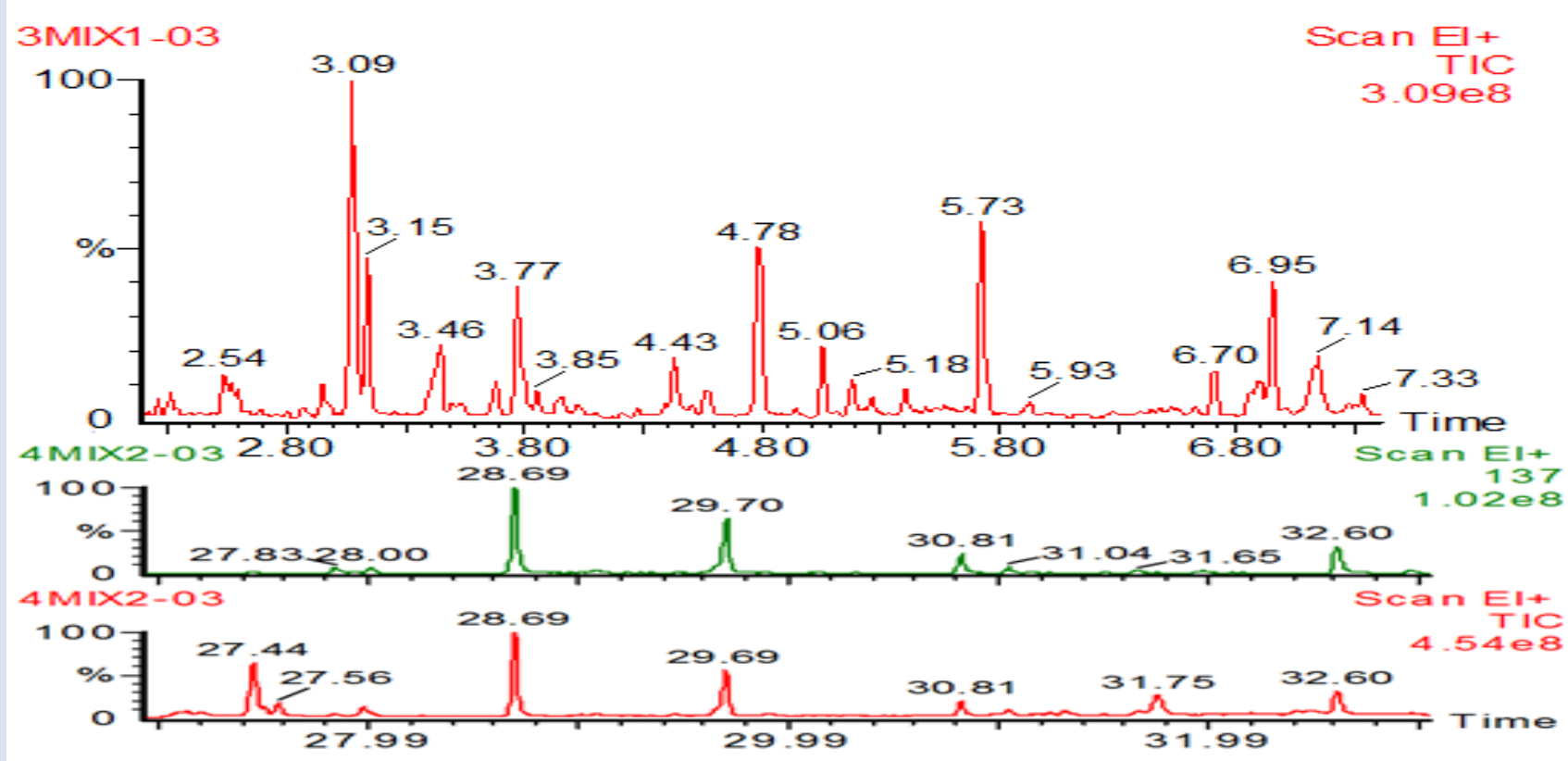

Figure 2: GC-MS of the extracts from natural mixtures 1 and 2. 


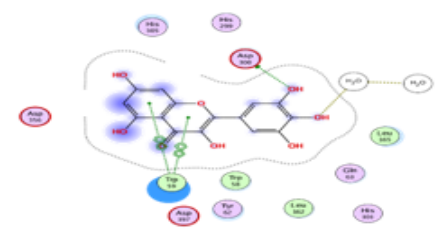

A
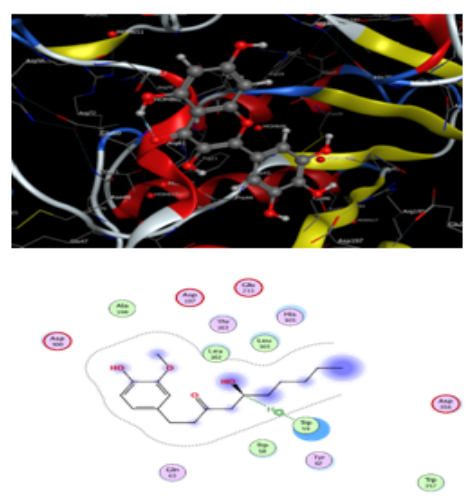

C

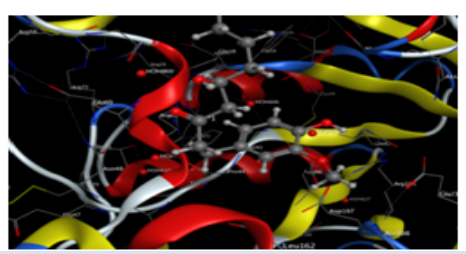

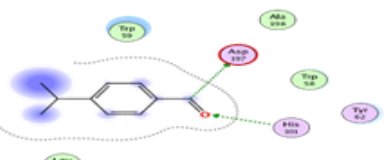

(ii)

(\$)

B

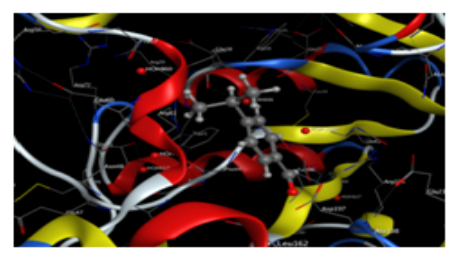

상

(बi) (T)

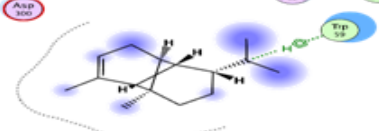

(ㄷiㄹ)

(iii) (5ii)

D

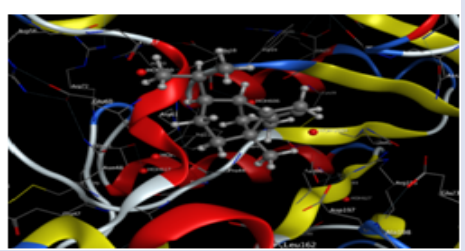

Figure 3 (1): Docking of compounds (A) Myricetin, (B) Cuminaldehyde, (C) Gingerol and (D) a-copaenein to h-PA active sites.
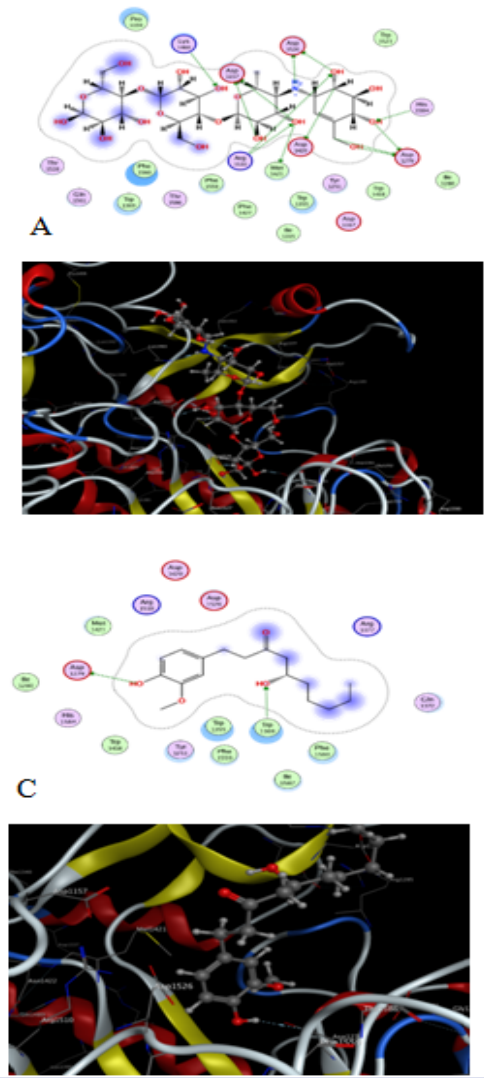

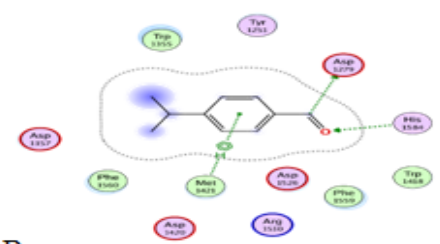

B
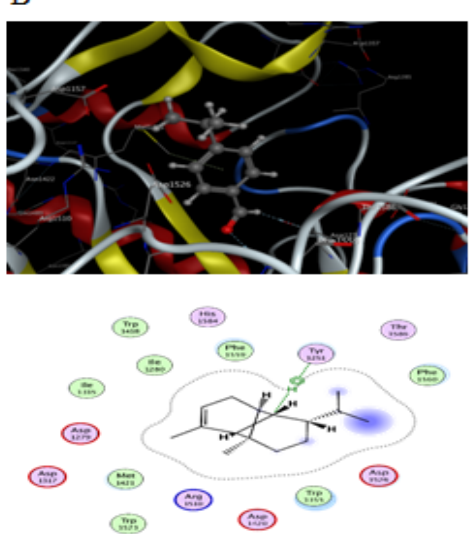

D

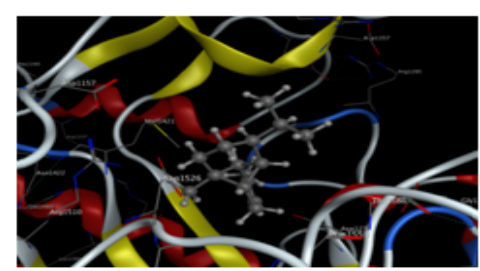

Figure 3 (II): Docking of compounds (A) Acarbose, (B)Cuminaldehyde, (C) Gingerol and (D) a-copaenein to h-MGAM-C active sites. 


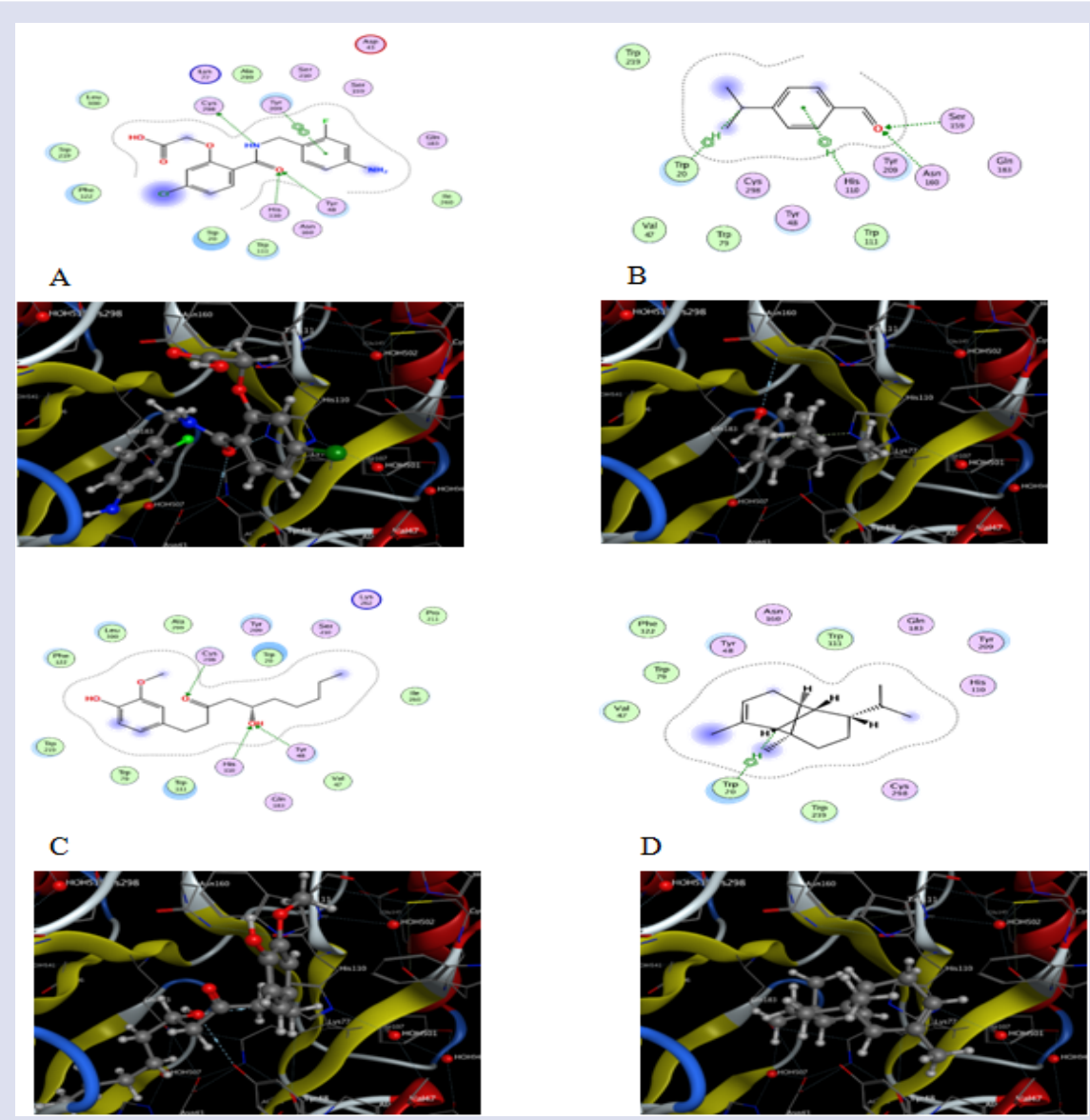

Figure 3 (III). Docking of compounds (A) AK198, (B) Cuminaldehyde, (C) Gingerol and (D) a-copaenein to h-ALR-2 active site.

of $-5.0865,-6.5708$, and $-4.5777 \mathrm{kcal} / \mathrm{mol}$ for Cuminaldehyde, Gingerol, and $\alpha$-copaene, respectively, compared with Acarbose docking score $(-9.6234 \mathrm{kcal} / \mathrm{mol})$ (Table 7).

Regarding h-MGAM-C ligands interactions at enzyme binding site, the antidiabetic Acarbose was found to afford several interactions with amino acids ASP-1157, ASP-1279, ASP-1420, MET-1421, LYS-1460, ARG-1510, ASP-1526, and HIS-1584. The results showed that the tested compounds exhibited interactions with some of aforementioned amino acids at enzyme binding site, such as Cuminaldehyde showed binding interactions with ASP-1279, MET-1421, and HIS-1584, Gingerol had binding interactions with ASP-1279, and TRP-1369 as will as $\alpha$-copaene had binding interactions with TYR-1251 (Figure 3-II).

For the third target enzyme, h-ALR-2 that is involved in glucose reduction and accumulation of sorbitol, the main causative of diabetes complications and the binding free energy of the tested compounds showed favorable docked complexes with the active site with significant docking scores of $-5.1308,-7.8558$, and $-5.3897 \mathrm{kcal} / \mathrm{mol}$ for Cuminaldehyde, Gingerol, and a-copaene, respectively. Compared with AK198 docking score $(-8.0848 \mathrm{kcal} / \mathrm{mol})$ (Table 7)

Regarding the interactions at h-ALR-2 enzyme binding site, AK198 showed binding interactions with TYR-48, HIS-110, TYR-209, and CYS-298 amino acids. while, Gingerol showed excellent binding interactions similarity with AK198 as it bound with three out of four amino acids that interacted with AK198 (TYR-48, HIS-110, and CYS298 amino acids ${ }^{24}$. While, Cuminaldehyde interacted with amino acids TRP-20, HIS-110, SER-159, and ASN-160, a-copaene had binding interactions with only TRP-20 amino acid (Figure 3-III).
From the results among the three tested compounds, Gingerol, had the best binding free energy and showed the best binding interactions with all target enzymes.

Score; lower scores are more favorable, rmsd_refine; The mean square root deviation of the pose from the docking pose relative to the position of the co-cristal ligand, E_conf; The conformer free binding energy, $\mathbf{E}_{-}$ place; free binding energy from the stage of placement, $\mathbf{E} \_$score 1; free binding energy from stage one of the rescoring, $\mathbf{E} \_$refine; free binding energy from the refinement stage, $\mathbf{E} \_$score 2; free binding energy from the second rescoring stage.

Treatment employing two or more herbs in combination known as, "polyherbal therapy" has the benefit of achieving optimum medicinal effectiveness at a lower dosage than a conventional herbal remedy. Because of the existence of large spectrum of phyto-bioactive ingredients, polyherbal therapy may have synergistic, potential pharmacological properties inside itself.

The present study focused on evaluating the pharmacological activity and possible benefit associated with the combination therapy relative to traditional anti-diabetic treatment, Glimepiride. Hyperglycaemia caused by alloxan has been identified as a valuable laboratory model for testing the action of hypoglycemic agents because alloxane, $\beta$-cytototoxin induces significant degradation of $\beta$-cells in Langerhans islets which result in decreased synthesis and release of insulin.

Diabetes caused by alloxane is characterised by a reduction of body weight and elevated food consumption. Body weight loss may result from protein wastage due to carbohydrate metabolism deficiency and excessive tissue protein breakdown ${ }^{25}$. The decrease in blood glucose 
was more significant $(\mathrm{P}<0.05)$ with the combination therapy than the single treatment. There appears to be a common assumption that the synergistic therapeutic effects of these mixtures were resulting from the interactions between the numerous bioactive constituents within the herbal preparations.

Our results showed that alloxan caused significant increase in serum urea and decrease in serum albumin level in diabetic animals when compared with normal control mice. These results are agreed with those reported by previous report ${ }^{26}$. This may due to metabolic disturbance in diabetes reflected in high activities of xanthine oxidase, lipid peroxidation, and increased triacylglycerol and cholesterol levels. Similar results were showing the increased concentrations of urea and creatinine due to excessive lipolysis in severe diabetes mellitus leading to ketosis and later on to acidosis ${ }^{27}$. Alloxan-induced diabetes triggered liver morphological and ultrastructural changes that closely resembled human disease, ranging from steatosis to steatohepatitis and liver fibrosis, therefore the current study focused on liver histopathology study $^{28}$.

Treatment of diabetic mice with the herbal mixtures 1 and 2 or glimepiride reduced fasting blood glucose level, serum urea nitrogen comparing to diabetic control group. Such an effect may be accounted for in part by a decrease in the mice of intestinal glucose absorption achieved by an extra pancreatic action including the stimulation of peripheral glucose utilization or enhancing glycolytic and glycogenic process with concomitant decrease in glycogenolysis and gluconeogenesis ${ }^{29}$.

Many Studies showed that the rate of kidney cell damage (nephropathy) in diabetes disorders increased significantly hyperglycaemia increases the production of free radicals by auto-oxidation of glucose and the increase of free radicals can cause damage to the renal cells $\mathrm{s}^{30}$. Reduction in plasma albumin was observed in alloxan induced mice which may be due to microproteinuria and albuminuria, which is an important clinical marker of diabetic nephropathy or may be due to increased protein catabolism ${ }^{30,31}$.

In plant phytochemical screening, the presence of flavonoids, alkaloids, glycosides, phenolics and tannins is likely responsible for the antidiabetic effects and enhancement of kidney and liver functions ${ }^{32}$. For this reason, we concentrated on organic extract for discovering the activity of long chain hydrocarbons, oils and non-polar components. It could be inferred from the overall results of the biochemical and histopathological tests that the organic extract from mixtures 1 and 2 showed a beneficial effect on the renal function in alloxan-induced diabetic mice (especially at a dose of $10 \mathrm{mg} / \mathrm{kg} \mathrm{IP}$ ).

Both of the organic extracts of mixture 1 and 2 showed a protective effect on the liver tissue in addition to its potent anti-diabetic activity. According to GC-MS results the major components in mixture 1 were palmitic acid, ethyl palmitate, in addition to minor amount of cuminaldehyde. It was reported that cuminaldehyde showed reduction in blood glucose level without causing hypoglycemia or $\beta$-cell exhaustion $^{33}$. This fact was confirmed by our histopathological results ${ }^{34}$.

It was previously mentioned that exposure to diet with high amount of palmitic acid inhibits the autophagic flux and decreases insulin sensitivity in hypothalamic neurons. Also palmitic acid showed lipotoxicity through elevation of triglyceride and oxidative stress ${ }^{35}$.

Our finding demonstrate that the potent antidiabetic activity of herbal mixture 1 was related to cuminaldehyde despite its lower concentration in addition to its protective effect against the lipotoxicity and action of palmitic acid on liver tissue. All these results together can introduce strong evidence on interaction between bioactive compounds in herbal mixtures. For mixture 2 the major compounds were Gingerol, Curcumin, several hydrocarbons and minor amount of $a$-Copaene.
It was reported that Gingerol has antidiabetic activity through various mechanisms, curcumin also decrease blood glucose level, and the levels of glycosylated hemoglobin in diabetic rats over the ruling of polyol pathway $^{36,37}$. a-Copaene as one of the essential oil components of Sabina chinensis had an inhibitory activity of $\alpha$-amylas ${ }^{38}$.

Our results revealed that herbal mixture 2 with several antidiabetic ingredients can have multiple targets, suggesting that activity can be accomplished by the synergistic and dynamic interactions between these multiple components.

Molecular docking of cuminaldehyde, Gingerol and a-Copaenin at the active site of the human pancreatic enzymes $\alpha$-amylase, maltaseglucoamylase and aldol reductase showed that all these test compounds had a strong binding affinity at the active sites of the enzymes. Implying that these substances could be mixed with promising drugs in the future for the treatment of diabetes.

Histopathological results revealed that the synergistic action between these several potent antioxidant materials could decrease the progress of liver injury.

The organic extracts of herbal mixture number 3, 4, 5 and 6 failed to show any protection in the progress of liver injury suggesting that the reason is inhibitory action between their components despite antidiabetic activity of each component extract alone.

Both of the mixtures 3 and 6 showed a potent harmful effect on the liver tissues as compared to diabetic control mice which give strong evidence for herb- herb interaction.

\section{CONCLUSION}

The current study found that the combination therapy, as designed in mixtures 1 and 2, provided medical benefits. As a result, a safe and effective herbal mixture for the treatment of diabetes was created. This mixture contains anti-diabetic Gingerol compounds that work to lower glucose levels, as well as Palmitic acids, Cuminaldehyde and $\alpha$-copaene which improve hyperglycemia. A potent and safe anti-diabetic herbal formula will be suggested.

The herb-herb interaction was proven in this study through synergistic action of compounds in mixture land 2 and inhibitory action of compounds in mixtures 4 and 5 in addition to harmful interaction between compounds in mixtures 3 and 6 .

\section{ABBREVIATIONS}

Diabetes mellitus (DM); De-paraffinized xylene (DPX); Gas chromatography mass spectromery (GC-MS); Total ion chromatogram (TIC); Human pancreatic a-amylase (h-PA); Human maltaseglucoamylase (h-MGAM-C); Human aldol reductase( h-ALR-2); Molecular Operating Environment program (MOE); vascular congestion (VC); Amyloidosis(AM); Hepatocyte degeneration (HD); Hepatocyte necrosis(NC); Central vein(CV); The conformer free binding energy (E_conf); Free binding energy from the stage of placement (E_place); Free binding energy From stage one of the rescoring (E_score 1); Free binding energy from the refinement stage(E_refine); Free binding energy from the second rescoring stage (E_score 2).

\section{FUNDING}

There is no outsourced or insourced funding involved in this research.

\section{AVAILABILITY OF DATA AND MATERIALS}

The data sets from this analysis are available upon request from the corresponding author. 


\section{AUTHORS' CONTRIBUTIONS}

Conceptualization Asmaa Sayed Abd Elkarim, Samah Shabana, A.H. A.and A.M. Elgamal. Data curation, GC Mass A. Khedr. Pharmacology, Histopathology, Biochemistry M. F. Shalaby and Roula Bayram, Molecular docking, Radwan Elhaggar. Resources A. S. Abd Elkarim and R. Bayram.Writing original draft S. Shabana.Writingreview and editing A. S. Abd Elkarim. InvestigationS. Shabana and A. S. Abd Elkarim. Formal analysis Radwan Elhaggar, A. Khedr and M. F. Shalaby.

\section{COMPETING INTERESTS}

The authors declare that they have no conflicts of interest.

\section{REFERENCES}

1. Bilous R, Donnelly R: Handbook of Diabetes. Wiley凶Blackwell Publication, vol 3 (4th.ed.) Oxford; 2010, p. 248.

2. Alotaibi A, Perry L, Ghlizadeh L, Al-Ganmi A. Incidence and prevalence rates of diabetes mellitus in Saudi Arabia: An overview. J Epidemiol. Community Health 2017; 7(4): 211-218.

3. Al Darwish A, Robert A, Braham R, Al Hayek A A, Al Saeed, A, Ahmed A R, et al. Mellitus in Saudi Arabia: A Review of the Recent Literature. Curr. Diabetes Rev. 2016; 12(4): 359-368.

4. Forouhi G, Wareham J: Epidemiology of diabetes. Medicine, vol. 42. (Abingdon, England UK ed.) England, 2014; 42(12):698-702.

5. Alhowaish K. Economic costs of diabetes in Saudi Arabia. J Fam Community Med. 2013; 20(1): 1-7.

6. Kearns K, Dee A, Fitzgerald A P, Doherty E, Perry I J. Chronic disease burden associated with overweight and obesity in Ireland: the effects of a small BMI reduction at population level. BMC Public Health. 2014; 14(1):1-10

7. Lucchesi N, Cassettari L, Spadella T. Alloxan-Induced Diabetes Causes Morphological and Ultrastructural Changes in Rat Liver that Resemble the Natural History of Chronic Fatty Liver Disease in Humans. J of diabetes Res. 2015; 2015: 494-578.

8. Kaneto $H$, Nakatani $Y$, Kawamori D, Miyatsuka T, Matsuoka T A, Matsuhisa $M$, et al. Role of oxidative stress, endoplasmic reticulum stress, and c-Jun $\mathrm{N}$-terminal kinase in pancreatic beta-cell dysfunction and insulin resistance. Int J Biochem Cell Biol. 2006; $38(5-6): 782-93$.

9. Khan ZA, Farhangkhoee H, Chakrabarti S. Towards new molecular targets for chronic diabetic complications. Curr Vasc Pharmacol. 2006; 4 (1): 45-57.

10. Davi G, Falco A, Patrono C. Lipid peroxidation in diabetes mellitus. Antioxid Redox Signa. 2005; 7(1-2): 256-68

11. Rezaei A, Farzadfard A, Amirahmadi A, Alemi M, Khademi M. Diabetes mellitus and its management with medicinal plants: A perspective based on Iranian research. J. Ethnopharmacol. 2015; 4(175):567-616.

12. Malviya N, Jain S, Malviya S. Antidiabetic Potential of Medicinal Plants. Acta Poloniae Pharmaceutica Drug Research. 2010; 67(2):113-118.

13. Cocchetto D, Bjornsson T. Methods for vascular access and collection of body fluids from the laboratory rat. J Pharm Sci. 1983; 72(5): 465-492.

14. Ladrière L, Malaisse-Lagae F, Fuhlendorff J, Malaisse WJ. Repaglinide, glibenclamide and glimepiride administration to normal and hereditarily diabetic rats. Eur J Pharmacol. 1997; 24(23): 227-34.

15. El-Ouady F, Eddouks M. Aqueous Asteriscus graveolens Extract Exhibits Antidiabetic and Hepatoprotective Effects in Diabetic Rats. J. Nat. prod. 2020; 10(4): 459
16. Doumas W, Watson A, Biggs H. Albumin standards and the measurement of serum albumin with bromcresol green. Clin Chim Acta $1971 ; 31(1): 87-96$.

17. Kaplan A: Urea nitrogen and urinary ammonia. In: Meites, S, vol. 5 (ed.), Standard Method of Clinical Chemistry. Academic Press Inc., New York, 1965, pp. 245- 256.

18. Kleiner E, Brunt M, Natta V. Design and validation of a histological scoring system for nonalcoholic fatty liver disease. Hepatology. 2005; 41 (6): 1313-1321.

19. Mukherjee I. Medical laboratory technology. Tata Mc Graw Hill. 1988; 3:991-993.

20. Youssef S, Ashour M, Ebada S, Sobeh M, El-Beshbishy H A, Singab, A N , et al. Antihyperglycaemic activity of the methanol extract from leaves of Eremophilamaculata (Scrophulariaceae) in streptozotocininduced diabetic rats. J Pharm Pharmacol. 1917; 69(6):733-742.

21. Nichols B, Quezada R, Robayo C, Ao Z, Hamaker R, Butte F et al. Mucosal maltase-glucoamylase plays a crucial role in starch digestion and prandial glucose homeostasis of mice. J Nutr. 2009; 139(4):684-690.

22. Mooradian A, Thurman J. Drug therapy of postprandial hyperglycaemia. Drugs. 2012; 57(1999):19-29.

23. Yabe-N C. Aldose reductase in glucose toxicity: a potential target for the prevention of diabetic complications. Pharmacol Rev. 1998: $50(1): 21-34$.

24. Ramana VK. Aldose reductase: new insights for an old enzyme. Biomol Concepts. 2011; 2(1-2):103-114.

25. Szkudelski T. The mechanism of alloxan and streptozotocin action in B cells of the rat pancreas. Physiol Res. 2001; 50(6): 537-546.

26. Rashmi S K, Kumar D. Antidiabetic effect of Euphorbia hirta leaves in alloxan induced diabetic mice. Pharmacologyonline. 2010; 1:6169.

27. Mayne PD: Lipid metabolism. In: Clinical Chemistry in Diagnosis and Treatment, (London UK, 6th ed.) Clays publisher, 1993, pp. 240-243.

28. Ashraf H, Heidari R, Nejati V, Ilkhanipoor M. Aqueous extract of Berberisintegerrima root improves renal dysfunction in streptozotocin induced diabetic rats. Avicenna J Phytomed. 2013; 3(1): 82-90.

29. Luzi $P$, Rafi M A, Victoria $T$, Baskin $G$ B, Wenger $D$ A. Characterization of the rhesq2us monkey galactocerebrosidase (GALC) cDNA and gene and identification of the mutation causing globoid cell leukodystrophy (Krabbe disease) in this primate. Gen. 1997; 42(1):319-324.

30. Sugimoto H, Grahovac G, Zeisberg M, Kallur R. Renal fibrosis and glomerulosclerosis in a new mouse model of diabetic nephropathy and its regression by bone morphogenic protein-7 and advanced glycation end product inhibitors. Diabetes. 2007; 56(7):1825-33.

31. Bakris G L. Diabetic nephropathy: What you need to know to preserve kidney function. Postgrad Med. 1993; 93(5):89-93.

32. Almdal $\mathrm{T} P$, Vilstrup $\mathrm{H}$. Strict insulin therapy normalises organ nitrogen contents and the capacity of urea nitrogen synthesis in experimental diabetes in rats. Diabetes 1988; 31(2):114-122.

33. Panche N, Diwan D, Chandra R: Flavonoids: an overview. J Nutr Sci. 2016; 47(5):1-15.

34. Patil S, Takalikar S, Joglekar M, Haldavnekar, S, Arvindekar U Insulinotropic and $\beta$-Cell Protective Action of Cuminaldehyde, Cuminol and an Inhibitor Isolated from Cuminumcyminum in Streptozotocin-Induced Diabetic Rats. $\mathrm{Br} \mathrm{J}$ of Nutr. 2013; 110(8):1434-1443. 
35. Nemecz M, Constantin A, Dumitrescu M, Alexandru N, Filippi A, Tanko $\mathrm{G}$, et al. The Distinct Effects of Palmitic and Oleic Acid on Pancreatic Beta Cell Function: The Elucidation of Associated Mechanisms and Effector Molecules. Front. Pharmacol. 2019; 9 (2018): 1554

36. Son M, Miura Y, Yagasaki, K. Mechanisms for antidiabetic effect of gingerol in cultured cells and obese diabetic model mice. Cytotechnology. 2015; 67(4): 641- 652.
37. Pivari F, Mingione A, Brasacchio C, Soladati L. Curcumin and Type 2 Diabetes Mellitus. Prevention and Treatment. Nutrients. 2019; 11(8):1837.

38. Gu D, Fang C, Yang J, Li M, Liu H, Yang Y. Chemical composition and $\alpha$-amylase inhibitory activity of the essential oil from Sabina chinensis cv. Kaizuca leaves. Nat. Prod. Res. 2018; 32(6):711-713.

\section{GRAPHICAL ABSTRACT}

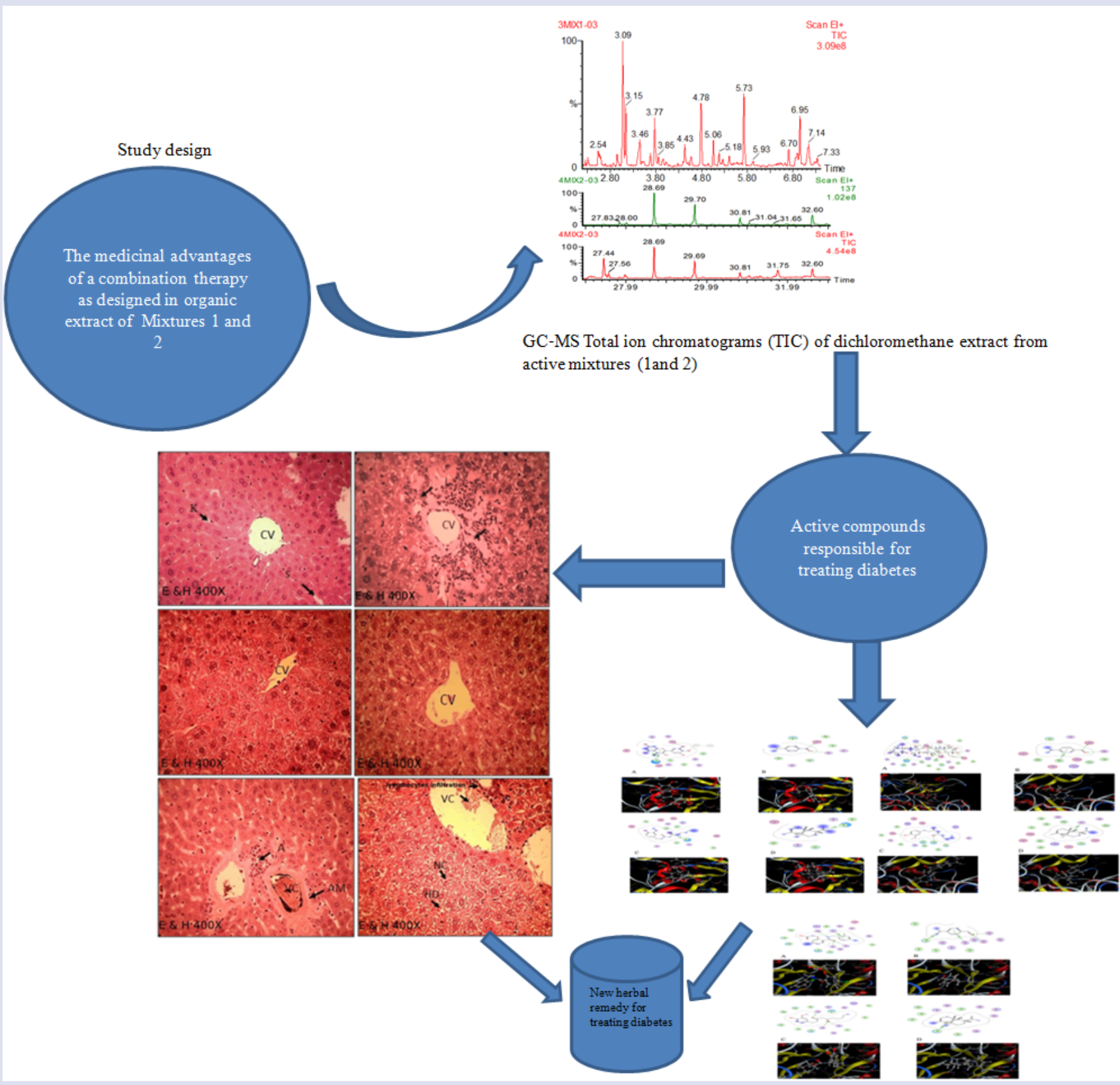

\section{ABOUT AUTHORS}

Asmaa Sayed Abd Elkarim: Researcher, Chemistry of Tanning Materials and Leather Technology Department, National Research Centre. 